the light scattering capacity and of the sedimentation velocity in the field of the ultracentrifuge (Institute for Physical Chemistry, The University, Uppsala, Sweden); Dr. E. S. Horning, to investigate by micro-incineration the relative distribution of the inorganic radicles of normal and tumour cells that have been exposed to various types of radiation (The Laboratory of the Imperial Cancer Research Fund, Queen Square, London); Dr. W. J. Dann, for work on the transmission of food vitamins by milk and the placenta, and the possible function of ascorbic acid (vitamin C) in oxidation mechanisms of the cell (Nutritional Laboratory, University of Cambridge) ; Mr. B. G. Maegraith, for work on methods of diagnosis and treatment of cerebrospinal meningitis (Dunn School of Pathology, University of Oxford); Mr. P. J. G. Mann, to investigate the functions of peroxidase às being chiefly an anabolic enzyme, and the action of vitamin $B$ as a possible co-enzyme of the lactic dehydrogenase system (Dunn Institute of Biochemistry, University of Cambridge); Dr. M. Stacey, to investigate carbohydrates yielded in the growth of moulds and of bacteria (Department of Biochemistry, London School of Hygiene and Tropical Medicine); Mr. A. H. Hughes, for work on surface films of molecules of biological importance, dealing in particular with hæmoglobin and the enzymes responsible for snake venom hæmolysis (Department of Colloid Science, University of Cambridge); Alison Sarah Dale, to investigate processes underlying the staircase phenomenon in amphibian and mammalian hearts (Pharmacological Laboratory, University of Edinburgh).

\section{Public Museums and Galleries in Great Britain}

IN its first report, the Standing Commission on Museums and Galleries, appointed in 1931 on a recommendation of the Royal Commission on the National Museums and Colloctions, fully justifies its existence (London : H.M. Stationery Office. 6d. net). The report is a document which merits the close attention of all who are interested in the promotion of scientifie and cultural studies or are concerned with the broader problems of education. It surveys the position of British public coliections and museums from three aspects. It deals first with the steps which have been taken to remedy the deficiencies to which the Royal Commission pointed, and to carry out the recommendations of that body. It then passes on to consider improvements in the utilisation of existing resources; and finally sketches an outline of further progress. It is plainly evident that the Committee, as a body composed largely of experts, which, as it were, holds a watching brief on behalf of the public and reports progress from time to time, is capable of fulfilling an increasingly useful function. As its work becomes more widely known, it should serve as a court of first instance for examining proposals to facilitate the fuller utilisation of museum collections by the public. In the period under review, for example, the Committee has had under consideration a scheme submitted by the Museums Association for promoting greater co-operation between the national collections and provincial institutions.
The Committee has been in a position to consult the authorities responsible for the national collections on these proposals, and as a result regional federations of provincial institutions are being established which will not only encourage freer and fuller intercourse between the institutions within each group, but will also further co-operation with local education authorities. Among suggestions for the future, the proposal that publicity officers should be added to the museum staff opens up a wide vista of possibilities.

\section{Scientific Utilisation of Coal}

THE economic production of liquid fuel and other products from coal is a subject which has received wide publicity. It formed the theme of Lord Rutherford's maiden speech delivered in the House of Lords a little more than two years ago, when as chairman of the Advisory Council of the Department of Scientific and Industrial Research he outlined the position and its prospects. Later in the same year Dr. C. H. Lander, then director of fuel research for the same Department, gave an informative Friday evening discourse at the Royal Institution (see Nature, April 30 and May 7, 1932), in which he gave figures showing the technical and economic aspects of the problem. It is of interest to note that the Miners' Federation also has the matter under consideration. At the final session on July 7 of the annual conference at Scarborough of the Federation, Mr. Sadler, of South Wales, moved a resolution urging the Trade Union Congress and the Labour party to press the Government to provide capital for establishing on an industrial basis the extraction of oil and by-products from coal. Coal, he said, made Great Britain the workshop of the world, and he asked the Conference to be prepared to make use of all the aid that science can give in utilising coal. Mr. Peter Lee (president) stated that he wanted to see coal used instead of oil wherever possible, but he emphasised also the importance of the scientific use of coal, adding that the Miners' Federation is fully aware of the possibilities. Mr. Sadler's resolution was adopted.

\section{American Museums of Natural History}

UNDer the title "The American Museum and Defeatism", the American Museum of Natural History, New York, in its annual report for the year 1932, records the strenuous and successful endeavour of the trustees and staff to "defeat defeatism", to use Prof. H. Fairfield Osborn's slogan. Notwithstanding the adverse conditions prevailing in the United States, the Museum carried on its various activities with a conspicuous measure of success, although some curtailment, involving reduction and retirement of staff and closure of some exhibition halls, proved unavoidable. Fortunately scientific exploration was affected only to a limited degree. Although the trustees were not able to continue the scientific explorations financed from their general funds, seventeen expeditions were sent out to various parts of the world for work in zoology, palæontology and anthropology, provision for these 
having been made by specific endowment. Advantage was taken of this enforced restriction in the activities of certain members of the scientific staff to proceed with research work and publication of results. The South Oceanic or Witney Wing was completed, one floor being adapted to house the Rothschild collection of birds, which has been acquired for the Museum by the widow and family of the late Mr. Harry Payne Witney. At the close of this, the twenty-fifth year of his tenure of office as president of the Museum, Prof. Osborn tendered his resignation, much to the expressed regret of the trustees and the authorities of the City of New York. Prof. Osborn has been succeeded as president by Prof. F. Trubee Davison; but in recognition of his great services to the Museum, Prof. Osborn has been elected honorary president for life.

\section{Excavations in Iraq}

According to a statement issued by Prof. J. H. Breasted and circulated by Science Service (Washington), after a visit to the various excavations in the Near East now being conducted by the Oriental Institute of Chicago, the tablet containing the list of kings of Assyria recently discovered at Khorsabad by the expedition under Dr. H. Frankfort, will shortly be shippod to the United States for study and publication. The lists are in cuneiform on two sides of a baked clay tablet and contain the names of ninetythree kings. They end about 730 B.c. just before the reign of Sargon II, which began in 722 B.c. As the lists cover a period of thirteen or fourteen hundred years, they carry back Assyrian history to about 2200 B.c. and add an unbroken line of eight new kings preceding Ushpia, previously the earliest known king, who ruled not long before 2000 B.c. Prof. Breasted also refers to the discovery at Khorsabad of the temple of $\mathrm{Nabu}$ or Nebo, mentioned by the prophet Isaiah, which he regards as one of the most important finds made by the expeditions of the Institute during the past season. As Nabu was the god of writing, his temple should, Prof. Breasted expects, contain records of importance. At Persepolis, where the excavations are in charge of Dr. E. N. Herzfeld, what would appear to be a library of records in the Elamite language has been unearthed in moving the field railroad. Although at present only very imperfectly examined, the tablets would appear to contain records connected with the building of the palaces.

Some further particulars of the results of the excavations of the Oriental Institute are given by Dr. H. Frankfort in a preliminary account in the Times of July 10 and 11. At Tell Asmar, a site on the east of the Tigris and Diala, fifty miles from Baghdad, identified with the ancient Eshnunna, in the course of a successful search for evidence which might afford chronological relation with the tombs of Ur, buildings were discovered belonging to the Akkadian period which have afforded the first view of the arrangements, domestic and other, of structures of the time of Sargon I. Dr. Frankfort notes that certain features of the elaborate sanitary system follow the European rather than the oriental type. A temple, "the House of Abu", Lord of Vegetation, originally founded in preAkkadian times but twice reconstructed, has yielded some remarkable reliefs, among which one represents the central mystery of the fertility cult, the marriage of the god and goddess, a subject of which there are hints in Babylonian texts, but no representation known elsewhere. Equally noteworthy are representations of the god partly in the form of a snake and of a deity attacking a sevenheaded monster with a spear, probably the oriental prototype of Heracles and the Hydra. A hoard of jewellery in a building of considerable size shows survivals from the period of the tombs of Ur. At Kafaje, a site 15 miles south-west of Tell Asmar, was found the earliest known example of town planning, in which closely packed houses of Sargonid date formed a long street running the whole length of the town from north-west to south-east, with side streets running at right angles from it. Dr. Frankfort considers that the evidence points to a closer relation of the region east of the Tigris to the mountaineers to the east and the north than to the Babylonians of the plains.

\section{Megaliths of the Trent Basin}

Bx the publication of the map of the Trent Basin (Ordnance Survey Office, Southampton. 4s, net) the scheme for a complete survey of the megalithic and allied remains of England and Wales is nearly halffinished. It is, in fact, the fourth of the series of twelve half-inch maps to be issued; and two more are in course of preparation. The survey of the Trent Basin is the work of Mr. C. W. Phillips. In one respect his work is especially noteworthy. It has resulted in the discovery of a previously unknown group of long barrows on the Lincolnshire Wolds, centred on two areas, the valley of the Swinhope Beck in the north and the terminal massif between Alford and Spilsby on the south, their distribution being rigidly confined to the chalk. Happily, it would appear, they have not been disturbed, except in two instances, in which digging does not appear to have penetrated to the deposit. It is regrettable that the same cannot be said of the western of the two groups into which the megalithic monuments of the area fall. In Derbyshire and on the confines of Cheshire and Staffordshire, the monuments, though not numerous, are among the most famous and interesting of their kind in England. Unfortunately, Arbor Low is the only one which has been investigated scientifically. The others were examined in the eighteenth or nineteenth century, and in some instances it is now impossible to determine their exact character archæologically, either from examination of the monuments themselves or the records where any exist. One feature in which the map of the Trent Basin differs conspicuously from its immediate predecessor, the map of Neolithic Wessex, is in the absence of any indication of ancient vegetation. This is due to differences of opinion among 'vegetarian experts'. 